International Journal of Current Microbiology and Applied Sciences

ISSN: 2319-7706 Volume 7 Number 07 (2018)

Journal homepage: http://www.ijcmas.com

\title{
Physiological Studies of Pathogens of Genus Botryosphaeria Isolated from Blue Pine (Pinus wallichiana) with Respect to their Carbon and Nitrogen Requirements
}

\author{
Shubana Bhat ${ }^{1}$, Shanaz Yousuf ${ }^{1}$, Farahanaz Rasool ${ }^{1}$ and Vikas Gupta ${ }^{2 *}$ \\ ${ }^{1}$ Division of Plant Pathology, SKUAST-Kashmir, India \\ ${ }^{2}$ Krishi Vigyan Kendra-Leh, SKUAST-Kashmir, India \\ *Corresponding author
}

\section{A B S T R A C T}

Keywords

Blue pine,

Botryosphaeria,

Carbon, Nitrogen

Article Info

Accepted:

24 June 2018

Available Online:

10 July 2018
Blue pine (Pinus wallichiana) plantations in Kashmir forests have been noticed to be affected by blight diseases showing typical symptoms of shoot blight, die-back and curling of terminal shoots. Plants grown in nutritionally poor soils are more susceptible to diseases. The type of major nutrient supplementation plays a major role in predisposition of plant to the infection by needle blight pathogens. Three fungi were isolated from the infected needles of Blue pine bearing fructification. Different carbon and nitrogen sources were assessed in a suitable medium to ascertain the most suitable nutrient elements for growth and development of these pathogens.

\section{Introduction}

Blue pine is prone to a number of diseases which pose serious threat to its regeneration. In the past few years, Blue pine (Pinus wallichiana) plantations in Kashmir forests have been noticed to be affected by several diseases showing typical symptoms of shoot blight, die-back and curling of terminal shoots (Palmer et al., 1987; Wingfield and KnoxDavies, 1980; Flowers et al., 2001). The nursery seedlings of $P$. wallichiana raised adjacent to infected plantations are more prone to these blight diseases which ultimately lead to the death of saplings (Douce et al., 2002). Many fungi are associated with blight diseases among which three fungi viz, Diplodia pinea, D. mutila and Fusicoccum aesculi, were frequently isolated from the diseased samples. These diseases were also observed on pine plantation in parks and garden giving the trees a shabby look. Nutrient status of a soil reflects the soil health and ultimately plant vigour. Generally plants grown in nutritionally poor soils are more susceptible to various diseases. The type of major nutrient supplementation plays a major role in predisposition of plant to the infection by needle blight pathogens. For 
instance, nitrogen fertilization in pine (Pinus nigra) plants increases bark necrosis and results in approximately longer shoot blight lesions caused by Sphaeropsis sapinea than in plants fertilized with potassium sulphate (De Kam et al., 1991). Similarly, phosphorus fertilization increases the susceptibility of young maritime pine (Pinus pinaster) to twisting rust (Melampsora pinitorqua) [Desprez-Loustau and Wagner, 1997]. In the present study, different carbon and nitrogen sources were assessed in a suitable medium to ascertain the most suitable nutrient elements for growth and development of pathogens.

\section{Materials and Methods}

To ascertain the most suitable nutrient elements for growth and development of pathogen(s), different carbon and nitrogen sources were assessed in Czapek's dox agar medium.

\section{Carbon source}

Effect of different carbon sources on radial mycelial growth and fructification of isolated pathogens was studied on Czapek's dox agar medium. The carbon source in basal medium was replaced separately by either of the four other carbon sources viz., glucose, fructose, lactose and mannitol (Qualigens/Hi-media). The quantity of carbon compounds added was determined on the basis of their molecular formulae so as to add an equivalent amount of carbon as was present in $30 \mathrm{~g}$ sucrose per litre Czapek's medium. Media without carbon source and with sucrose as carbon source served as checks. The media containing different carbon compounds were sterilized by autoclaving at $1.05 \mathrm{~kg} \mathrm{~cm}^{-1}$ for 20 minutes, except for the media containing disaccharide supplements such as lactose and sucrose which were boiled for 30 minutes on three consecutive days at zero pressure for sterilization to avoid hydrolysis. The $\mathrm{pH}$ of each medium was adjusted to 6.0. After pouring equal volumes of medium in sterilized petriplates (90 $\mathrm{mm}$ dia.), $3 \mathrm{~mm}$ discs from 14 days old vigorously growing culture were inoculated on media and incubated at $25 \pm 1^{\circ} \mathrm{C}$ for 21 days. Three replications were maintained for each medium under aseptic conditions in a completely randomized design (CRD). The observations on radial mycelial growth were recorded after 4 days. The fungal fructification was estimated by counting the average number of pycnidia produced in one square centimetre surface area, recording the observation from centre, middle and the periphery of petriplates.

\section{Nitrogen source}

The sodium nitrate in basal Czapek's Dox Agar Medium was replaced separately with either of the four different nitrogen sources viz., potassium nitrate, ammonium nitrate, ammonium sulphate and urea (Qualigens/Himedia). The concentrations of nitrogen supplements was adjusted in such a manner that the amount of nitrogen was equivalent to that present in $2.0 \mathrm{~g}$ sodium nitrate. The basal medium without nitrogen compound and with sodium nitrate as nitrogen source served as checks. The experiment was conducted in CRD with each treatment replicated three times. Before autoclaving, the $\mathrm{pH}$ in each medium was adjusted to 6.0. The inoculations, incubations and observations regarding radial mycelial growth and fructifications were performed as described earlier in carbon source.

\section{Results and Discussion}

\section{Carbon source}

To assess the best carbon source for the growth of $D$. pinea, $D$. mutila and F.aesculi,five carbon sources, namely sucrose, glucose, fructose, lactose and mannitol were 
evaluated in vitro. Czapek's dox agar medium without sucrose served as check. The radial mycelial growth and pycnidial production of the test pathogens was recorded on $4^{\text {th }}$ and $21^{\text {st }}$ days of incubation at $25 \pm 1{ }^{\circ} \mathrm{C}$, respectively (Table-1). In case of $D$. pinea, glucose, sucrose and fructose were the most preferred carbon sources yielding maximum radial mycelial growth of 85.3, 76.0 and $75.5 \mathrm{~mm}$, respectively; and all these sources were at par. Lactose gave radial mycelial growth of 51.60 $\mathrm{mm}$. Mannitol was the least preferred carbon source exhibiting radial mycelial growth of $29.60 \mathrm{~mm}$ which was at par with check $(28.40$ $\mathrm{mm}$ radial growth). The pycnidial production in $D$. pinea varied significantly with carbon source. The pycnidial production was maximum $\left(6.00 / \mathrm{cm}^{2}\right)$ in medium containing glucose as carbon source followed by fructose $\left(5.60 / \mathrm{cm}^{2}\right)$, sucrose $\left(5.10 / \mathrm{cm}^{2}\right)$, lactose $\left(3.10 / \mathrm{cm}^{2}\right)$, mannitol $\left(2.80 / \mathrm{cm}^{2}\right)$ and check $\left(1.00 / \mathrm{cm}^{2}\right)$. The data regarding D. mutila (Table-1) revealed that radial mycelial growth and pycnidial production per unit surface area of the media also increased significantly on different carbon sources as compared to check. Glucose and fructose were the most preferred carbon sources yielding maximum radial mycelial growth of $63.73 \mathrm{~mm}$ and 63.00 $\mathrm{mm}$ followed by sucrose $(41.73 \mathrm{~mm})$ and lactose $(30.33 \mathrm{~mm})$. Mannitol was the least preferred carbon source exhibiting radial mycelial growth of only $28.90 \mathrm{~mm}$ compared to $25.00 \mathrm{~mm}$ radial mycelial growth obtained in absence of any carbon source. The pycnidial production too varied significantly with different carbon source amendments whereas no pycnidia were produced in the absence of carbon source. The pycnidial production was maximum $\left(5.80 / \mathrm{cm}^{2}\right)$ with glucose as carbon source followed by fructose $\left(5.50 / \mathrm{cm}^{2}\right)$, sucrose $\left(4.90 / \mathrm{cm}^{2}\right)$, mannitol $\left(3.10 / \mathrm{cm}^{2}\right)$ and lactose $\left(2.00 / \mathrm{cm}^{2}\right)$ as carbon source whereas least pycnidial production $\left(1.00 / \mathrm{cm}^{2}\right)$ was observed in the absence of any carbon source. The data regarding F. aesculi
(Table-1) revealed that radial mycelial growth and the pycnidial production per unit surface area of the media too varied significantly on different carbon sources as compared to check. Fructose $(85.00 \mathrm{~mm})$ and glucose $(84.73 \mathrm{~mm})$ were the most preferred carbon sources yielding maximum radial mycelial growth followed by sucrose $(80.73 \mathrm{~mm})$ and lactose $(54.50 \mathrm{~mm})$. Mannitol was the least preferred carbon source exhibiting radial mycelial growth of only $30.13 \mathrm{~mm}$ compared to $28.00 \mathrm{~mm}$ radial mycelial growth obtained in absence of any carbon source. The pycnidial production was maximum $\left(5.50 / \mathrm{cm}^{2}\right)$ with glucose as carbon source followed by fructose $\left(5.20 / \mathrm{cm}^{2}\right)$, sucrose $\left(4.40 / \mathrm{cm}^{2}\right)$, mannitol $\left(3.00 / \mathrm{cm}^{2}\right)$ and lactose $\left(1.70 / \mathrm{cm}^{2}\right)$ as carbon source, whereas least number of pycnidia i.e. $1.00 / \mathrm{cm}^{2}$ were produced in the absence of any carbon source. Carbon constitutes half of the dry weight of fungus and is not only the main structural element but a chief source of energy as well (Cochrane, 1958). The identification of a carbon source most suitable for the growth and fructification of particular fungus is of paramount significance. In case of $D$. pinea, D. mutila and F.aesculi glucose, sucrose and fructose were observed to be the most preferred carbon sources yielding maximum mycelial growth and fructification with slight variations. Lactose and mannitol were the least preferred carbon source for all the three test fungi. Our observations are more or less in agreement with Khan (2010) who reported maximum mycelial growth of $D$. seriata in media containing sucrose, glucose and fructose as carbon source. Latha et al., (2013) found sucrose,carboxy-methyl cellulose and glucose as carbon source in media induced highest mycelial growth and pycnidial production of Lasiodiplodia theobromea isolated from physic nut. Patil et al., (2006) and Saha et al., (2008) reported that of the various carbon sources evaluated for the growth of Botryodiplodia theobromea and $L$. 
Theobromea respectively, sucrose and glucose produced higher mycelial growth.

\section{Nitrogen source}

The radial mycelial growth and pycnidial production in medium having variable nitrogen sources were recorded on $4^{\text {th }}$ and $21^{\text {st }}$ day of incubation at $25 \pm 1^{\circ} \mathrm{C}$, respectively. In case of $D$. pinea, significant differences in radial mycelial growth and pycnidial production were observed with the changes in nitrogen source in basal medium (Table-2). Potassium nitrate proved best nitrogen source to sustain maximum radial mycelial growth of $82.86 \mathrm{~mm}$ which was followed by ammonium nitrate and ammonium sulphate with 72.68 and $71.75 \mathrm{~mm}$ mycelial growth. All the above nitrogen sources were at par. Urea and sodium nitrate as nitrogen source showed mycelial growth of 62.00 and $61.40 \mathrm{~mm}$ and were at par with ammonium nitrate and ammonium sulphate but differed significantly from control. The medium without any nitrogen source (control) yielded least fungal growth $(26.53 \mathrm{~mm})$. Maximum pycnidial production in $D$. pinea was observed on media containing potassium nitrate $\left(10.66 / \mathrm{cm}^{2}\right)$ and ammonium nitrate $\left(9.00 / \mathrm{cm}^{2}\right)$ as nitrogen sources which were at par. These were followed by sodium nitrate $\left(7.30 / \mathrm{cm}^{2}\right)$ and urea $\left(4.00 / \mathrm{cm}^{2}\right)$. Medium without nitrogen source produced least number of pycnidia $\left(1.30 / \mathrm{cm}^{2}\right)$ whereas medium with ammonium sulphate did not produce any pycnidia. The data regarding the test fungus $D$. mutila reveals significant differences in the radial mycelial growth and pycnidial production on different nitrogen sources in the substrate medium (Table-2). Potassium nitrate was the best nitrogen source to sustain maximum radial mycelial growth of $80.08 \mathrm{~mm}$ followed by ammonium nitrate with mycelial growth of $78.41 \mathrm{~mm}$. The other nitrogenous compounds in order of their decreasing preference were ammonium sulphate $(46.46 \mathrm{~mm})$, urea $(31.58 \mathrm{~mm})$ and sodium nitrate $(29.00 \mathrm{~mm})$. The medium without any nitrogen source yield fungal growth of $30.00 \mathrm{~mm}$. Maximum pycnidial production was found on media with ammonium nitrate $\left(5.33 / \mathrm{cm}^{2}\right)$ and potassium nitrate $\left(4.00 / \mathrm{cm}^{2}\right)$ as nitrogen sources followed by urea $\left(2.33 / \mathrm{cm}^{2}\right)$ and sodium nitrate $(1.66 /$ $\left.\mathrm{cm}^{2}\right)$. Least number of pycnidia $\left(1.00 / \mathrm{cm}^{2}\right)$ was produced in medium without any nitrogen source however no pycnidia were produced in ammonium sulphate. The data regarding the test fungus $F$. aesculi revealed significant differences in the radial mycelial growth and pycnidial production on different nitrogen sources in the substrate medium (Table-2). Potassium nitrate $(81.25 \mathrm{~mm})$ was the best nitrogen source to sustain maximum radial mycelial growth followed by ammonium nitrate with mycelial growth of $80.66 \mathrm{~mm}$. The other nitrogenous compounds in order of their decreasing preference were ammonium sulphate $(25.83 \mathrm{~mm})$, urea $(23.81 \mathrm{~mm})$ and sodium nitrate $(16.16 \mathrm{~mm})$. The medium without any nitrogen source yielded least fungal growth $(10.75 \mathrm{~mm})$. Maximum pycnidial production was found on media with ammonium nitrate $\left(4.50 / \mathrm{cm}^{2}\right)$ and potassium nitrate $\left(4.33 / \mathrm{cm}^{-2}\right)$ as nitrogen sources followed by urea $\left(1.75 / \mathrm{cm}^{2}\right)$. Least number of pycnidia $\left(1.00 / \mathrm{cm}^{2}\right)$ was produced in medium without any nitrogen source. However, no pycnidia were produced in media with ammonium sulphate and sodium nitrate. Nitrogen is the major nutrient element utilized by fungi for functional and structural purposes. In the present study potassium nitrate and ammonium nitrate were observed to be the most suitable nitrogen source for mycelial growth and fructification of all the three pathogens which indicated that these fungi utilized nitrogen source more preferably in nitrate form rather than ammonical form. Ammonium sulphate proved third best medium for mycelial growth only and no fructification was noticed in this medium. Other evaluated nitrogen sources viz., urea and 
sodium nitrate showed lesser mycelial growth as well as less or no fructification. The preference of nitrate-nitrogen by B.dothidea has also been reported by Pusy et al., (1995) and Khan (2010). Latha et al., (2013) while evaluating various ammonical nitrogen sources reported ammonium dihydrogen phosphate, ammonium oxalate, ammonium nitrate and ammonium sulphate as suitable nitrogen sources for the mycelial growth and pycnidia production in L. theobromea.

Table.1 Effect of different carbon sources amended in Czapek's dox agar medium on radial mycelial growth and pycnidial production of isolated pathogens after incubation at $25 \pm 1{ }^{\circ} \mathrm{C}$

\begin{tabular}{|c|c|c|c|c|c|c|}
\hline \multirow{3}{*}{ Carbon source } & \multicolumn{2}{|c|}{ Diplodia pinea } & \multicolumn{2}{|c|}{ Diplodia mutila } & \multicolumn{2}{|c|}{ Fusicoccum aesculi } \\
\hline & 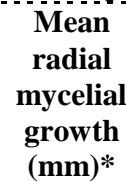 & $\begin{array}{c}\text { Pycnidial } \\
\text { production } \\
\left(\text { No. } \mathrm{cm}^{-2}\right)\end{array}$ & 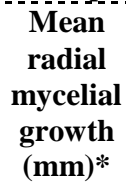 & $\begin{array}{c}\text { Pycnidial } \\
\text { production } \\
\left(\text { No. } \text { cm }^{-2}\right)\end{array}$ & 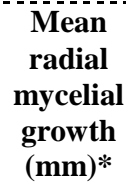 & $\begin{array}{c}\text { Pycnidial } \\
\text { production } \\
\left(\text { No. } \mathrm{cm}^{-2}\right)\end{array}$ \\
\hline & $\left(4^{\text {in }}\right.$ day $)$ & $\left(21^{\mathrm{si}}\right.$ day $)$ & $\left(4^{\text {th }}\right.$ day $)$ & $\left(21^{\text {st }}\right.$ day $)$ & $\left(4^{\text {th }}\right.$ day $)$ & $\left(21^{3 \mathrm{st}}\right.$ day $)$ \\
\hline Glucose & $85.33^{\mathrm{a}}$ & $6.00^{\mathrm{a}}$ & $63.73^{\mathrm{a}}$ & $5.80^{\mathrm{a}}$ & $84.73^{\mathrm{a}}$ & $5.50^{\mathrm{a}}$ \\
\hline Fructose & $75.50^{\mathrm{a}}$ & $5.60^{\mathrm{a}}$ & $63.00^{\mathrm{a}}$ & $5.50^{\mathrm{a}}$ & $85.00^{\mathrm{a}}$ & $5.20^{\mathrm{a}}$ \\
\hline Mannitol & $29.60^{c}$ & $2.80^{b}$ & $28.90^{c}$ & $3.10^{\mathrm{b}}$ & $30.13^{c}$ & $3.00^{b}$ \\
\hline Lactose & $51.60^{b}$ & $3.10^{\mathrm{b}}$ & $30.33^{c}$ & $2.00^{\mathrm{b}}$ & $54.50^{b}$ & $1.70^{\mathrm{c}}$ \\
\hline $\begin{array}{l}\text { Sucrose } \\
\text { (positive } \\
\text { check) }\end{array}$ & $76.00^{\mathrm{a}}$ & $5.10^{\mathrm{a}}$ & $41.73^{b}$ & $4.90^{\mathrm{a}}$ & $80.73^{\mathrm{a}}$ & $4.40^{\mathrm{a}, \mathrm{b}}$ \\
\hline $\begin{array}{l}\text { Check (no } \\
\text { carbon) }\end{array}$ & $28.40^{\mathrm{c}}$ & $1.00^{c}$ & $25.00^{c}$ & $1.00^{\mathrm{c}}$ & $28.00^{\mathrm{c}}$ & $1.00^{\mathrm{c}}$ \\
\hline $\mathrm{CD}(\mathrm{P} \leq \mathbf{0 . 0 5})$ & 13.20 & 1.49 & 7.32 & 1.45 & 15.19 & 1.40 \\
\hline
\end{tabular}

*The figures superscripted by the same letter are statistically at par with each other

Table.2 Effect of different nitrogen sources amended in Czapek's dox agar medium on radial mycelial growth and pycnidial production of isolated pathogens after incubation at $25 \pm 1{ }^{\circ} \mathrm{C}$

\begin{tabular}{|c|c|c|c|c|c|c|}
\hline \multirow{3}{*}{ Nitrogen source } & \multicolumn{2}{|c|}{ Diplodia pinea } & \multicolumn{2}{|c|}{ Diplodia mutila } & \multicolumn{2}{|c|}{ Fusicoccum aesculi } \\
\hline & $\begin{array}{l}\text { Mean } \\
\text { radial } \\
\text { mycelial } \\
\text { growth } \\
(\mathbf{m m})^{*}\end{array}$ & $\begin{array}{c}\text { Pycnidial } \\
\text { production } \\
\left(\text { No. } \mathrm{cm}^{-2}\right)\end{array}$ & $\begin{array}{c}\text { Mean } \\
\text { radial } \\
\text { mycelial } \\
\text { growth } \\
(\mathrm{mm}) *\end{array}$ & $\begin{array}{c}\text { Pycnidial } \\
\text { production } \\
\left(\text { No. } \mathrm{cm}^{-2}\right)\end{array}$ & $\begin{array}{l}\text { Mean } \\
\text { radial } \\
\text { mycelial } \\
\text { growth } \\
(\mathbf{m m})^{*}\end{array}$ & $\begin{array}{c}\text { Pycnidial } \\
\text { production } \\
\left(\text { No. } \mathrm{cm}^{-2}\right)\end{array}$ \\
\hline & (4 day) & $\left(21^{\mathrm{st}}\right.$ day $)$ & (4 day) & $\left(21^{\mathrm{st}}\right.$ day $)$ & $\left(4^{\text {th }}\right.$ day $)$ & $\left(21^{\mathrm{st}}\right.$ day $)$ \\
\hline Ammonium nitrate & $72.68^{\mathrm{a}, \mathrm{b}}$ & $9.00^{\mathrm{a}}$ & $78.41^{\mathrm{a}}$ & $5.33^{\mathrm{a}}$ & $80.66^{a}$ & $4.50^{\mathrm{a}}$ \\
\hline Ammonium sulphate & $71.75^{\mathrm{a}, \mathrm{b}}$ & $0.00^{\mathrm{e}}$ & $46.46^{\mathrm{b}}$ & $0.00^{\mathrm{e}}$ & $25.83^{\mathrm{b}}$ & $0.00^{\mathrm{c}}$ \\
\hline Potassium nitrate & $82.86^{\mathrm{a}}$ & $10.66^{\mathrm{a}}$ & $80.08^{a}$ & $4.00^{\mathrm{b}}$ & $81.25^{\mathrm{a}}$ & $4.33^{\mathrm{a}}$ \\
\hline Urea & $62.00^{\mathrm{b}}$ & $4.00^{c}$ & $31.58^{\mathrm{c}}$ & $2.33^{\mathrm{c}}$ & $23.81^{\mathrm{b}}$ & $1.75^{\mathrm{b}}$ \\
\hline $\begin{array}{l}\text { Sodium } \\
\text { nitrate(positive check) }\end{array}$ & $61.40^{\mathrm{b}}$ & $7.33^{\mathrm{b}}$ & $29.00^{\mathrm{c}}$ & $1.66^{\mathrm{c}}$ & $16.16^{\mathrm{b}, \mathrm{c}}$ & $0.00^{c}$ \\
\hline Check (no nitrogen) & $26.53^{c}$ & $1.30^{\mathrm{d}}$ & $30.00^{c}$ & $1.00^{\mathrm{d}}$ & $10.75^{\mathrm{c}}$ & $1.00^{b}$ \\
\hline $\mathrm{CD}(\mathrm{P} \leq \mathbf{0 . 0 5})$ & 12.23 & 1.79 & 10.33 & 1.14 & $\mathbf{1 0 . 4 2}$ & 1.02 \\
\hline
\end{tabular}

*The figures superscripted by the same letter are statistically at par with each other. 
In conclusion, all the pathogens with slight variation showed preference towards glucose, sucrose and fructose as carbon source for maximal radial mycelial growth and pycnidial production. Of the five nitrogen sources namely potassium nitrate, ammonium nitrate, ammonium sulphate, urea and sodium nitrate were evaluated in vitro for the growth of $D$. pinea, $D$. mutila and $F$. aesculi. Potassium nitrate and ammonium nitrate proved to be the best nitrogen source for all the pathogens to sustain maximum radial mycelial growth and pycnidial production with the exception that in case of D. mutila pycnidial production on potassium nitrate and ammonium nitrate differed significantly. No pycnidial production of test pathogens was observed on ammonium sulphate. It may be concluded that all the test pathogens grow best on glucose, fructose and sucrose among the carbon sources and on potassium nitrate, ammonium nitrate and ammonium sulphate among the nitrogen sources tested at $25 \pm 1^{\circ} \mathrm{C}$.

\section{References}

Cochrane, V. W. 1958. Physiology of Fungi. John Wiley and Sons, Inc. New York, USA. pp. 524.

De-kam, M., Versteegen, C. M., Van Den Burg, J. and Van Der Werf, D. C. 1991. Effect of fertilization with ammonium sulphate and potassium sulphate on the development of Sphaeropsis sapinea in Corsican pine. Netherlands Journal of Plant Pathology, 97: 265-274.

Douce, G.K., Moorhead, D.J. and Bargeron, C.T. 2002. Forest Pest Control.Special Bulletin 16.College of Agricultural and Environmental Sciences, the University of Georgia, USA. (http://www.bugwood.org/ pestcontrol/index.html).

Flowers, J., Nuckles, E., Hartman, J. and Vaillancourt, L. 2001. Latent infection of Austrian and Scots pine tissues by Sphaeropsis sapinea.Plant Disease 85: 1107-1112.
Khan, N. A. 2010. Status and Etiology of Canker Diseases of Apple in Kashmir. Ph.D. Thesis. Department of Plant Pathology. S.K. University of Agricultural Sciences \& Technology, Shalimar, Kashmir, India. p. 76.

Latha, P., Prakasam, V., Jonathan, E. I., Samiyappan, R. and Natarajan, C. 2013. Effect of culture media and environmental factors on mycelial growth and pycnidial production of Lasiodiplodia theobromea in Physic nut (Jatropha curcas). Journal of Environmental Biology 34: 683-687.

Palmer, M. A., Stewart, E. L. and Wingfield, M. J. 1987. Variation among isolates of Sphaeropsis sapinea in the North Central United States. Phytopathology77: 944948.

Patil, L. V., Shinde, V. B, Ghawade, R. S. D. and Wavare, S. H. 2006. Physiological and nutritional studies of Botryodiplodia theobromea Pat. causing die-back disease of mango. Journal of Plant Disease Science 1: 216-218

Pusy, P. L., Kitajima, H. and Wu, J. M. 1995. Peach tree fungal gummosis by Botryosphaeria dothidea. In: Compendium of Stone Fruit Disease (Eds. Ogawa, M.J., Zehr, E.I., Bird, G.W., Ritchie, D.F., Uriu, K. and Uyemoto, J. K.). APS press. The American Phytopathological Society, St. Paul, Minnesota, USA. Pp. 33-34

Saha, A., Mandal, P., Dasgupta, S. and Saha, D. 2008. Influence of cultural media and environmental factors on mycelial growth and sporulation of Lasiodiplodia theobromea (Pat.) Griffon and Maubl. Journal of Environmental Biology, 29: 407-410.

Wingfield, M. J. and Knox-Davies, P. S. 1980.Association of Diplodia pinea with a root disease of pines in South Africa. Plant Disease 64: 221-223.

\section{How to cite this article:}

Shubana Bhat, Shanaz Yousuf, Farahanaz Rasool and Vikas Gupta. 2018.Physiological Studies of Pathogens of Genus Botryosphaeria Isolated from Blue Pine (Pinus wallichiana) with Respect to their Carbon and Nitrogen Requirements. Int.J.Curr.Microbiol.App.Sci. 7(07): 3099-3104. doi: https://doi.org/10.20546/ijcmas.2018.707.361 